\title{
COMPARISON OF POTENTIAL ENVIRONMENTAL IMPACTS ON THE PRODUCTION AND USE OF HIGH AND LOW SULFUR REGULAR DIESEL BY LIFE CYCLE ASSESSMENT
}

\author{
Aldemar Martínez-González ${ }^{1 *}$, Oscar-Mauricio Casas-Leuro ${ }^{2}$, Julia-Raquel Acero-Reyes ${ }^{2}$, and \\ Edgar-Fernando Castillo-Monroy ${ }^{2}$ \\ ${ }^{1}$ Ambiocoop Ltda., Piedecuesta, Santander, Colombia \\ 2 Ecopetrol S.A. - Instituto Colombiano del Petróleo (ICP), A.A. 4185 Bucaramanga, Santander, Colombia \\ e-mail: aldemar.martinez@ecopetrol.com.co
}

(Received May. 31, 201 1; Accepted Oct. 27, 2011)

\begin{abstract}
T

his paper provides a comparative analysis using the concept of life cycle assessment (LCA), between highsulfur (3 000 ppm) and low-sulfur diesel $(500$ ppm) diesel. The comparative LCA considers the stages of production, transport and oil refining, as well as the transport of refined products and their respective end use. This last stage of the life cycle is important for the analysis of potential environmental impacts, due to sulfur oxide $\left(\mathrm{SO}_{\mathrm{x}}\right.$ ) emissions, which contribute to the formation of acid rain, damage air quality and the ecosystem (land and water acidification), causing gradual damage to human health and the environment. Therefore, comparative LCA identifies critical points from the environmental perspective, weighing the contributions of pollutants $\left(\mathrm{NO}_{2}, \mathrm{CH}_{4}\right.$ and $\left.\mathrm{CO}_{2}\right)$ known as greenhouse gases $(\mathrm{GHG})$ and criteria pollutants $(\mathrm{CO}, \mathrm{SO}$, NOxw, VOC's and $P M)$. Simapro 7,2 ${ }^{\circledR}$ was used to simulate and evaluate potential environmental impacts generated during the production and use by end consumers of the two fossil fuels. In order to evaluate the impact categories, two methods available in said calculation tool were selected: the first is the IPCC-2007 (GWP-100 years), which estimates the carbon footprint and the contributions of each stage of the production chain to the "Global Warming" effect. The second method of evaluation is the Impact 2002+, which assesses the various contributions to the categories of toxicity to "Human Health", "Ecosystem Quality", "Climate Change" and "Depletion of Natural Resources". Thus, the preliminary results of comparative LCA show a slight increase in the carbon footprint (total emissions of $\mathrm{CO}_{2}$ equivalent in the productive chain) of low-sulfur diesel, approximately 3,8\% compared to high-sulfur diesel, as a result of the increased emissions generated by the operation of the hydrogenation plant. However, low-sulfur diesel achieves a significant reduction of about $80 \%$ in comparison with high-sulfur diesel, in terms of damage to "Human Health" and "Ecosystem Quality". On the contrary, there was an increase of $2 \%$ and $6 \%$ in the categories of "Climate Change" and "Depletion of Natural Resources", respectively. Finally, despite the minor increase in the carbon footprint, although with remarkable reductions in "Ecosystem Quality" and "Human Health", the production and use of low-sulfur diesel has a single score of environmental impact equivalent to 0,23 milli points (mPt) compared to the single score obtained by high-sulfur diesel of 1,23 (mPt).
\end{abstract}

Keywords: Diesel fuel, Emissions, Sulfur oxides, Impact categories, Carbon footprint, Hydrogenation plant, Single score.

Citation: Martínez-González, A., Casas-Leuro, O. M., Acero-Reyes, J. R. \& Castillo-Monroy, E. F. (201 1). Comparison of potential environmental impacts on the production and use of high and low sulfur regular diesel by life cycle assessment. CT\&F - Ciencia, Tecnología y Futuro, 4 (4), 123 - 138.

*To whom correspondence should be addressed 


\section{RESUMEN}

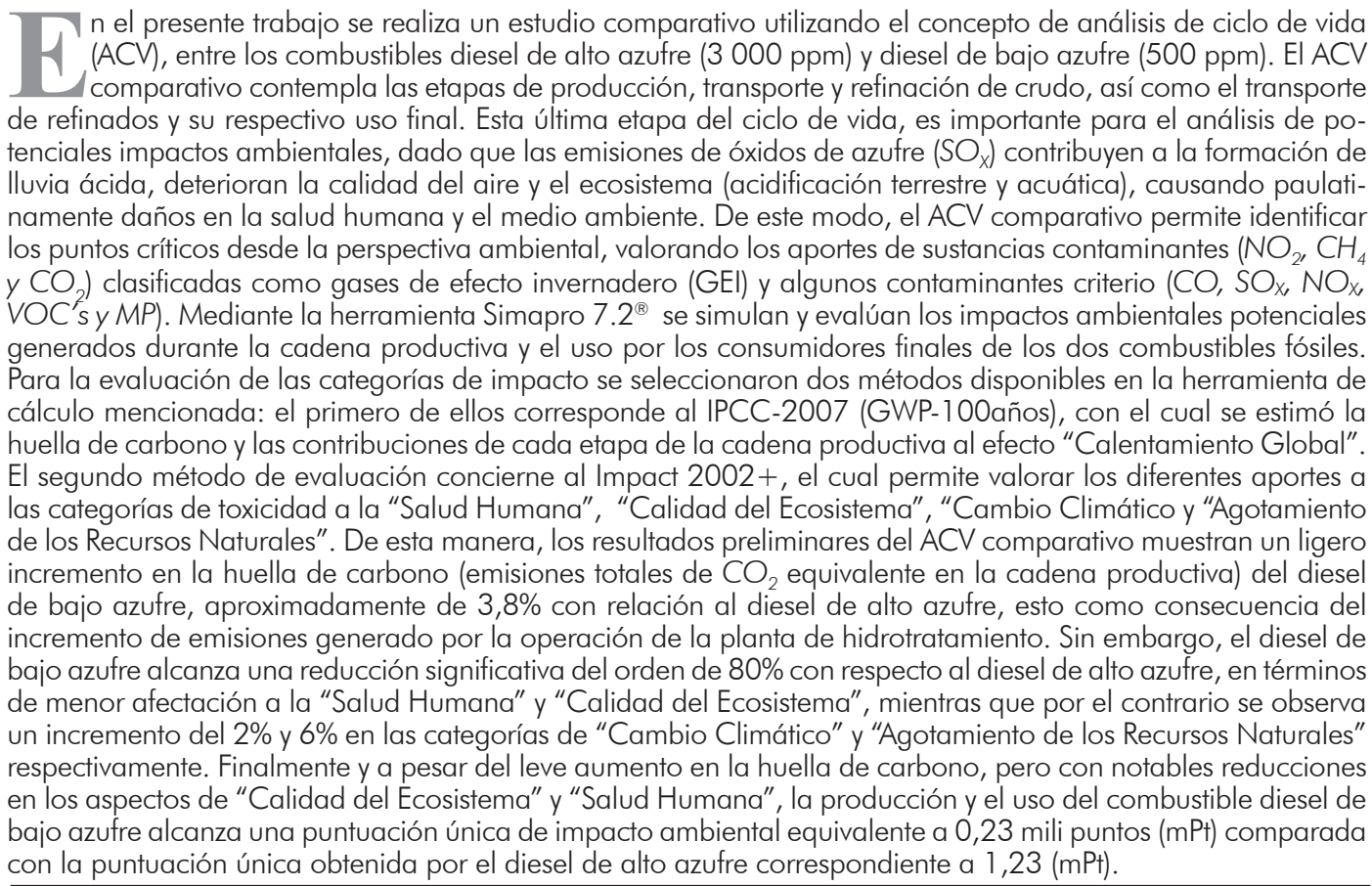

Palabras claves: Combustible diesel, Emisiones, Oxidos de azufre, Categorías de impacto, Huella de carbono, Planta de hidrotratamiento, Puntuación única.

\section{RESUMO}

$\mathrm{N}$ o presente trabalho é realizado um estudo comparativo utilizando o conceito de análise de ciclo de vida (ACV), entre os combustíveis diesel de alto teor de enxofre (3000 ppm) e diesel de baixo teor de enxofre $(500 \mathrm{ppm})$. O ACV comparativo contempla as etapas de produção, transporte e refinação de cru, assim como o transporte de refinados e seu respectivo uso final. Esta última etapa do ciclo de vida é importante para a análise de potenciais impactos ambientais, dado que as emissões de óxidos de enxofre $\left(\mathrm{SO}_{\mathrm{x}}\right)$ contribuem para a formação de chuva ácida, deterioram a qualidade do ar e do ecossistema (acidificação terrestre e aquática), causando paulatinamente danos para a saúde humana e para o meio ambiente. Deste modo, o ACV comparativo permite identificar os pontos críticos desde a perspectiva ambiental, avaliando as contribuições de substâncias contaminantes $\left(\mathrm{NO}_{2}, \mathrm{CH}_{4} \mathrm{e} \mathrm{CO}_{2}\right)$ classificadas como gases de efeito estufa (GEI) e alguns contaminantes critério $\left(\mathrm{CO}, \mathrm{SO}_{x}, \mathrm{NO}_{x}, \mathrm{VOC}^{\prime}\right.$ 's e MP). Mediante a ferramenta Simapro $7.2^{\circledR}$ são simulados e avaliados os impactos ambientais potenciais gerados durante a cadeia produtiva e $\mathrm{o}$ uso pelos consumidores finais dos dois combustíveis fósseis. Para a avaliação das categorias de impacto foram selecionados dois métodos disponíveis na ferramenta de cálculo mencionada: o primeiro deles corresponde ao IPCC-2007 (GWP-100 anos), com o qual foi estimada a pegada de carbono e as contribuições de cada etapa da cadeia produtiva para o efeito "Aquecimento Global". O segundo método de avaliação concerne ao Impact 2002+, - qual permite avaliar as diferentes contribuições para as categorias de toxicidade para a "Saúde Humana", "Qualidade do Ecossistema", "Mudança Climática" e "Esgotamento dos Recursos Naturais". Desta maneira, os resultados preliminares do ACV comparativo mostram um leve aumento na pegada de carbono (emissões totais de $\mathrm{CO}_{2}$ equivalente na cadeia produtiva) do diesel de baixo teor de enxofre, aproximadamente de $3,8 \%$ com relação ao diesel de alto enxofre, isto como consequência do aumento de emissões gerado pela operação da planta de hidrotratamento. Porém, o diesel de baixo teor de enxofre alcança uma redução significativa da ordem de $80 \%$ com relação ao diesel de alto teor de enxofre, em termos de menor afetação para a "Saúde Humana" e "Qualidade do Ecossistema", enquanto que ao contrário é observado um aumento de $2 \%$ e $6 \%$ nas categorias de "Mudança Climática" e "Esgotamento dos Recursos Naturais" respectivamente. Finalmente, e apesar do leve aumento na pegada de carbono, mas com notáveis reduções nos aspectos de "Qualidade do Ecossistema" e "Saúde Humana", a produção e o uso do combustível diesel de baixo teor de enxofre alcança uma pontuação única de impacto ambiental equivalente a 0,23 mili pontos (mPt) comparada com a pontuação única obtida pelo diesel de alto teor de enxofre correspondente a 1,23 (mPt).

Palavras-chaves: Combustível diesel, Emissões, Óxidos de enxofre, Categorias de impacto, Pegada de carbono, Planta de hidrotratamento, Pontuação única. 


\section{INTRODUCTION}

One of the main environmental concerns at the global level with regard to the use of fossil fuels has to do with sulfur oxide $\left(\mathrm{SO}_{2}\right.$ and $\left.\mathrm{SO}_{3}\right)$ emissions generated during combustion and their potential impact on air quality, contribution to the formation of acid rain and the acidification of soil and bodies of water (Menz \& Seip 2004). During the combustion process, sulfur $(S)$ turns mainly into $\mathrm{SO}_{3}$, which reacts to steam and forms sulfuric acid $\left(\mathrm{H}_{2} \mathrm{SO}_{4}\right)$. Some of these particles (known as ultrafine particles) are considered particularly dangerous due to their ability to penetrate deep into the lungs (Cape, 2003). According to the US Environmental Protection Agency (EPA), approximately 2\% of the sulfur in diesel fuel becomes direct emissions of particulate matter (MP), where the latter, together with sulfur and nitrogen oxides ( $S O_{X}$ and $N O_{X}$ respectively) damage air quality and cause gradual damage to human health (Sydbom et al., 2001). It can be established that PM consists of three main components: a carbon core, a soluble organic fraction (SOF) and a mixture of $S_{X}$ and water; when combined, these elements have shown significant carcinogenic levels in humans (Stanislaus, Abdulazeem \& Mohan, 2010).

On the other hand, many countries and international organizations have taken the initiative to develop strict environmental policies focused on sustainable development and social wellbeing. Regulations have been developed on the quality parameters to be met by fossil fuels, in which sulfur content (maximum allowable level) is one of the most relevant requirements. For the first time, the US reduced sulfur levels in fossil diesel from $2000 \mathrm{ppm}$ to $500 \mathrm{ppm}$ during the 1990 's, through the Clean Air Act (CAA); after that, sulfur levels dropped to $350 \mathrm{ppm}$ and $15 \mathrm{ppm}$ during the years 2000 and 2006, respectively (Mester, 2000). In turn, countries like Germany obtained a sulfur limit in diesel of about 10 ppm as of January 2003, while other countries of the European Union and Japan introduced a fuel with $10 \mathrm{ppm}$ on the market as of the year 2008 (Plantenga \& Leliveld, 2003). These quality requirements as regards sulfur content are within the specifications of the World Wide Fuel Charter (WWFC), where fossil diesel should have a low sulfur content, as illustrated in Table 1. In addition, it has to satisfy a minimum cetane index and significant reductions in polynuclear aromatic compounds (PNA) (Stanislaus et al., 2010).
Table 1. Parameters of the World Charter for diesel fuel category 4. (Stanislaus et al., 2010).

\begin{tabular}{cc|}
\hline Parameters' & Value \\
Density, max $(\mathrm{g} / \mathrm{cm})^{3}$ & 0,840 \\
\hline Sulfur $-\mathrm{S}(\mathrm{ppm})$ & $5-10$ \\
\hline Cetane Index & $\geq 52$ \\
\hline Aromatics & $<15$ vol.\% \\
\hline${ }^{\text {'PNA }}$ & $<2$ vol.\% \\
\hline Temperature $_{90}\left(\mathrm{max}^{\circ} \mathrm{C}\right)$ & 320 \\
\hline Temperature $_{95}\left(\mathrm{max}^{\circ} \mathrm{C}\right)$ & 340 \\
\hline
\end{tabular}

'PNA: Poly-nuclear aromatic compounds

Over the last two decades, Ecopetrol S.A. has made major efforts and investments to improve the quality of the fossil fuels (mainly diesel and gasoline) produced at its refineries in Colombia. In the case of diesel, modifications and improvements were made between 1990 and 2001 in the refining processes, which led to significant reductions in sulfur content in a fraction of the regular diesel produced by Ecopetrol S.A., dropping from $5000 \mathrm{ppm}$ to $1200 \mathrm{ppm}$. With the implementation of integrated mass transit systems in some Colombian cities starting in the year 2001, and pursuant to the new regulations on diesel quality established by government authorities, a $500 \mathrm{ppm}$ diesel fuel (a mixture of 1200 ppm diesel and imported diesel with $10 \mathrm{ppm}$ of sulfur) was introduced in 2008, for the above-mentioned mass transit systems; the $3000 \mathrm{ppm}$ diesel is for users from the rest of the country (Arango, 2009). It is very important to point out that the startup of Ecopetrol's hydro-diesel treatment plant (HDT) at the Barrancabermeja refinery in 2010 ensures the production of $300 \mathrm{ppm}$ gasoline, $50 \mathrm{ppm}$ diesel for the mass transportation system nationwide, and several cities in Colombia (Bogotá and Medellín), while $500 \mathrm{ppm}$ diesel is distributed for the rest of the country in compliance with the current Colombian legislation (Law 1205 / 2008). The entire country is expected to have $50 \mathrm{ppm}$ diesel by December 31, 2012 (Téllez, 2010).

\section{Technologies to Reduce Sulfur in Fossil Fuels}

Hydrotreatment is one of the technologies most commonly used by crude refineries to remove sulfur from the raw materials and products (gasoline and diesel). Typical reactions that occur during hydrotreatment 
by hydrogen injection are catalytic hydrodesulfurization, as well as hydrodenitrogenation, hydrodeoxygenation, and finally, hydrodearomatization. (Chunshan \& Xiaoliang, 2009).

In compliance with the Colombian regulations contained in Law 1205 / 2008 and Resolution 182087 / 2007 of the Ministry of Environment, Housing and Territorial Development (MAVDT) and the Ministry of Mines and Energy (MME), Ecopetrol started operating a hydrotreatment plant (HDT) in 2010, which is expected to produce approximately 47,2 tons less sulfur emissions into the atmosphere per day. However, the operation of the plant also uses more hydrogen (obtained from the catalytic reforming of fossil natural gas), in addition to a new energy requirement for refining. Therefore, it is not clear at first, what the final effect of adopting a new sulfur standard for these fuels will be on the accepted environmental impact categories (including Global Warming). Furthermore, these changes in the refined end products can have an impact on the exhaustion of natural resources, and the modification of GHG emissions units can be expected.

The purpose of this paper is to compare, from the viewpoint of environmental sustainability, two production scenarios: the chain of processing and using high sulfur regular diesel (DS3000) and low-sulfur regular diesel (DS500) produced up to the reference year of 2008 for Colombia. In order to do so, the study contrasts the potential environmental impacts (Global Warming) and the evaluation of the effect on the quality of air we breathe, for each of the scenarios mentioned above, using the life cycle analysis methodology as an assessment tool. This methodology is based on international standards (ISO 14044) and impact assessment methods, such as the IPCC 2007 (GWP-100a) developed by the Intergovernmental Panel on Climate Change (IPCC) and the Impact 2002+ method.

\section{METHODOLOGY}

A Life Cycle Analysis (LCA) study, from the conceptual standpoint, consists of the following stages: (I) LCA characteristics, (II) Inventory analysis and (III) Impact assessment. As regards the first item, certain parameters are to be established, such as the definition of the functional unit, the product system and its limits, and the impact categories to be assessed. After that, inventory is taken (process information) and validated. Finally, environmental impacts are assessed using a calculation tool and by selecting an impact assessment method. Figure 1 illustrates the stages of the LCA methodology and some of the aspects to be addressed in the development there of, as established in ISO 14044.

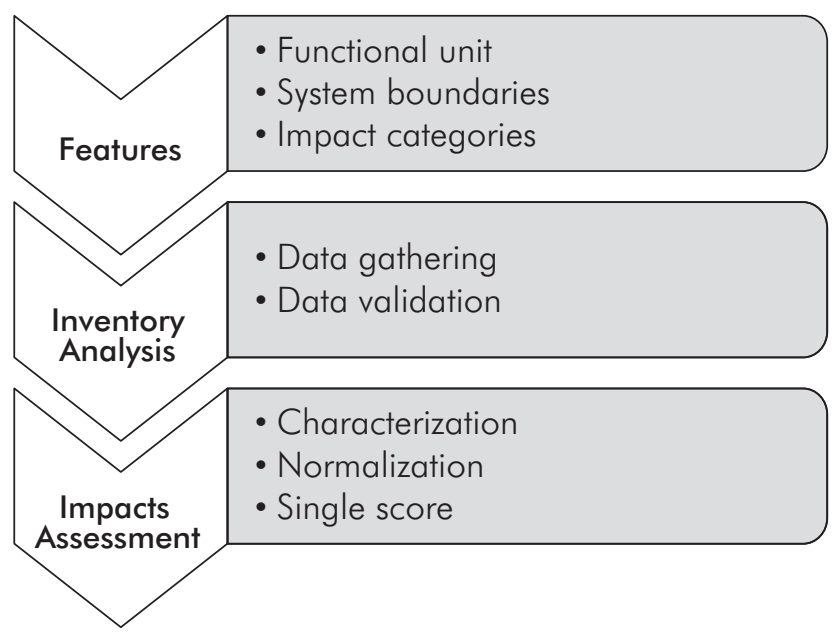

Figure 1. Stages of the life cycle analysis methodology.

\section{Characteristics of Comparative LCA}

The scope has to be defined in order to apply the LCA methodology. In this case, it includes the stages of crude production (see the main production fields below), transport (main transport stations associated with the feed at the refinery), refining and the transport of refined products to the Puente Aranda Station (Bogotá D. C.). It also includes the end use of the fuel, based on the emission factors obtained in the EU Ecoinvent database. The scope of this paper does not contemplate the refined product distribution chain between wholesalers and retailers. Thus, Figure 2 illustrates the production chain of the fuels under study called DS3000 and DS500, which are high and low sulfur regular diesel, respectively. The functional unit selected for the chain to process and obtain regular diesel is $1 \mathrm{MJ}$ of fossil fuel produced, while for the final stage of use, the consumption of fossil fuel equivalent to $1 \mathrm{MJ}$ has been chosen according to the low calorific value thereof. 


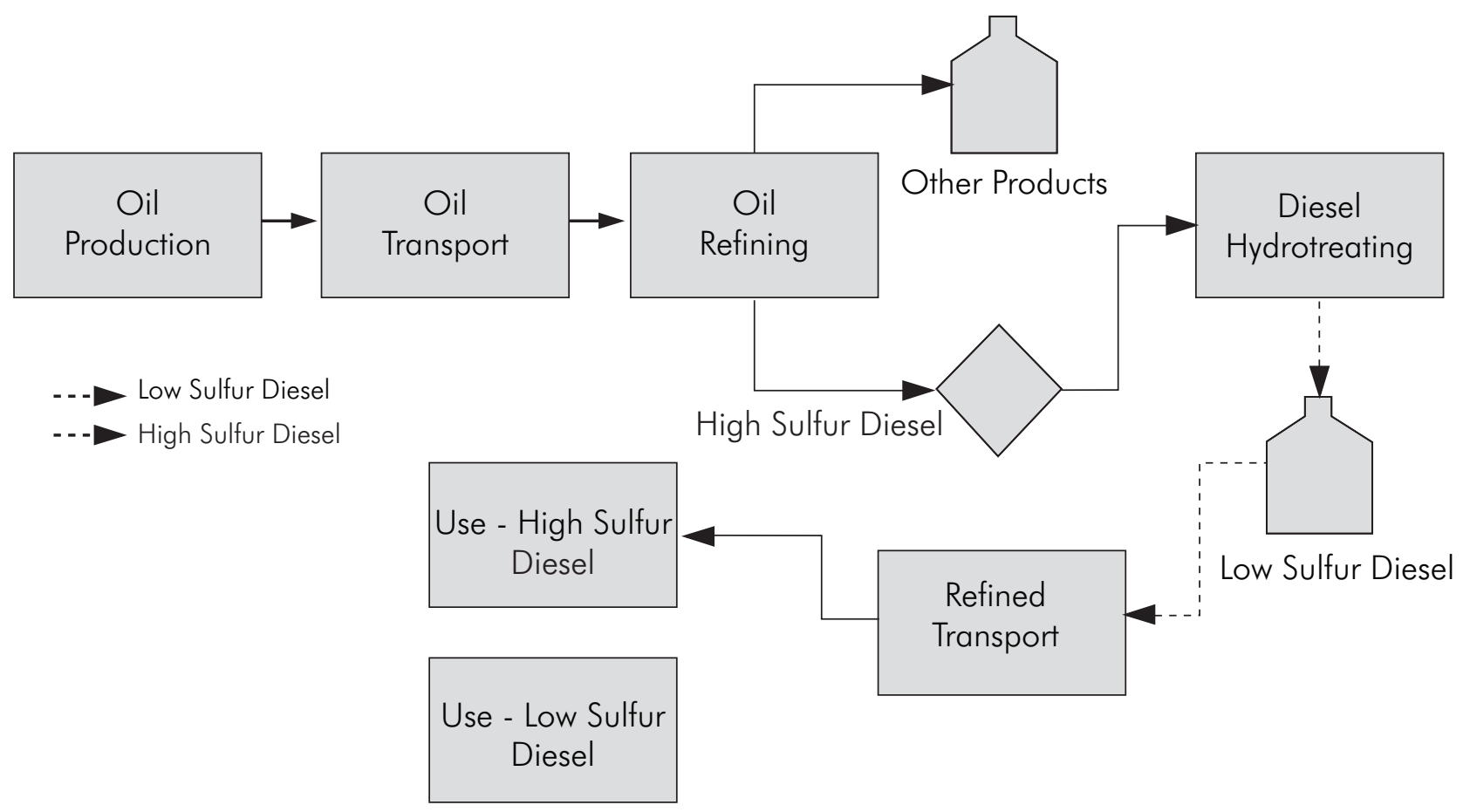

Figure 2. Regular diesel production chain of high-sulfur (DS3000) and low sulfur (DS500).

\section{Inventory Analysis}

Taking inventory includes estimating emissions into the air throughout the chain (from production to transport to the wholesale site), classified as direct (combustion processes), indirect (external electric power), vents and fugitive emissions (Herrera \& Martínez, 2009), where the main polluting substances are distributed in two groups: the first pertains to greenhouse gases $\left(\mathrm{NO}_{2}, \mathrm{CH}_{4}\right.$ and $\left.\mathrm{CO}_{2}\right)$, while the other group is made up of criteria pollutants $\left(\mathrm{CO}, \mathrm{SO}_{\mathrm{X}}, \mathrm{NO}_{\mathrm{X}}, V O C^{\prime} \mathrm{s}\right.$ and $\left.\mathrm{PM}\right)$. Both the emissions inventory and the information on the processes (energy and mass balances) associated with the production of DS3000 are from the year of operation 2008, which is the reference year for this study.

In the case of the DS500 diesel production, there is no information available for the reference year (2008), because production of this fuel began at the end of the year 2010. Therefore, a hypothetical scenario for the production and use of DS500 diesel has been simulated, maintaining the same scheme adopted in the production of DS3000 diesel (Figure 2), except for certain modifications, including: the inclusion of a hydrotreatment process at the refining stage, which involves a higher demand for hydrogen, along with its consequent increase in the consumption of fossil fuels and emissions.

\section{Impact Assessment}

Simapro $7.2^{\circledR}$ is used to assess the proposed cases and their potential associated environmental impacts throughout the life cycle. Similarly, the method developed by the IPCC 2007 (GWP-100 years) has been selected to assess impact, in order to evaluate the impact category corresponding to "global warming". In the meantime, to assess categories of potential impact other than global warming, such as: "land and water acidification" and "generation of respirable organic and inorganic compounds" using Simapro $7.2^{\circledR}$, other methods are required, such as the Impact $2002+$ proposed by Jolliet et al. (2003). Figure 3 describes the stages followed to assess environmental impacts using the Impact $2002+$ method, where the first step is to classify and add each of the pollutants in equivalent units and by impact categories, using specific characterization factors for each substance. So in the case of the "global warming" category, the unit of measure is $\mathrm{kg} \mathrm{CO}_{2}$-eq (carbon dioxide), while the compounds with the most contribution to this 


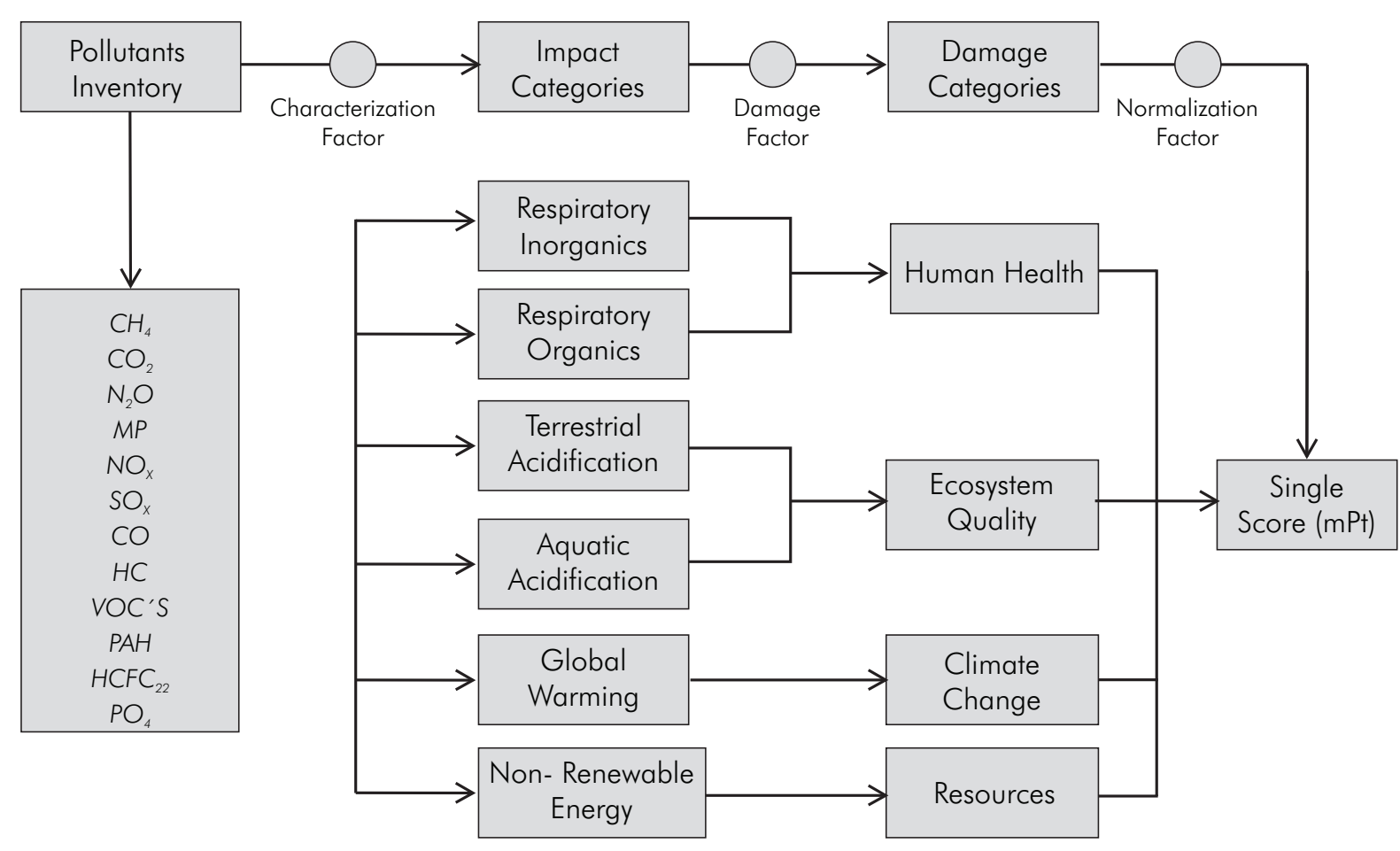

Figure 3. Steps for environmental impact assessment according to Impact 2002+ method.

category are $\mathrm{NO}_{2}, \mathrm{CH}_{4}$ y $\mathrm{CO}_{2}$, with characterization factors equivalent to: 310,21 and $1 \mathrm{~kg} \mathrm{CO}$-eq $/ \mathrm{kg}$ of substance, respectively. Once the polluting substances of inventory have been processed in equivalent units, they are added and classified by impact categories. Six impact categories have been identified for this study: "Respirable Organic and Inorganic", "Land and Water Acidification", "Global Warming" and "Non-renewable Energy".

The second step of the Impact 2002+ methodology lies in the transformation of impact categories and subsequent aggregation in the final categories (Figure 3), through fate factors described by Jolliet et al. (2003). Therefore, the environmental impact assessment is narrowed down to four global categories of potential impact: "Human Health", "Ecosystem Quality", "Climate Change" and "Depletion of Natural Resources". The third and final stage of the environmental impact assessment consists of converting each of the categories established in the previous phase into a single variable known as "Single Score" based on the standardization factors defined by Jolliet et al. (2003). The "Single Score" variable is measured in units of milli-points
$(\mathrm{mPt})$, which indicate the potential number of people affected by the environmental impacts taken into consideration over a period of one year (Jolliet et al., 2003).

On the other hand, the following are some of the main considerations made at each of the stages of the DS500 and DS3000 regular diesel production chain:

\section{Crude Production}

There are three major equivalent fields where crude is produced onshore to be sent to the Barrancabermeja Refinery to obtain refined products. These equivalent fields are Magdalena Medio, Caño Limon and Apiay, as illustrated in Figure 4. While Table 2 shows the main emissions factors and products established in the equivalent production fields.

- In each of the equivalent fields, a record was kept of the consumption of electric energy from the National Grid (SIN in Spanish) and associated indirect emissions of $\mathrm{CO}_{2}$-eq. In order to do so, the emission factor in electric power generation in Colombia, which is $0,2849 \mathrm{~kg} \mathrm{CO}$-eq $/ \mathrm{kW} \cdot \mathrm{h}$ was taken (Ministerio de Minas y Energía, Colombia, Resolution 180947/ June 4, 2010). 


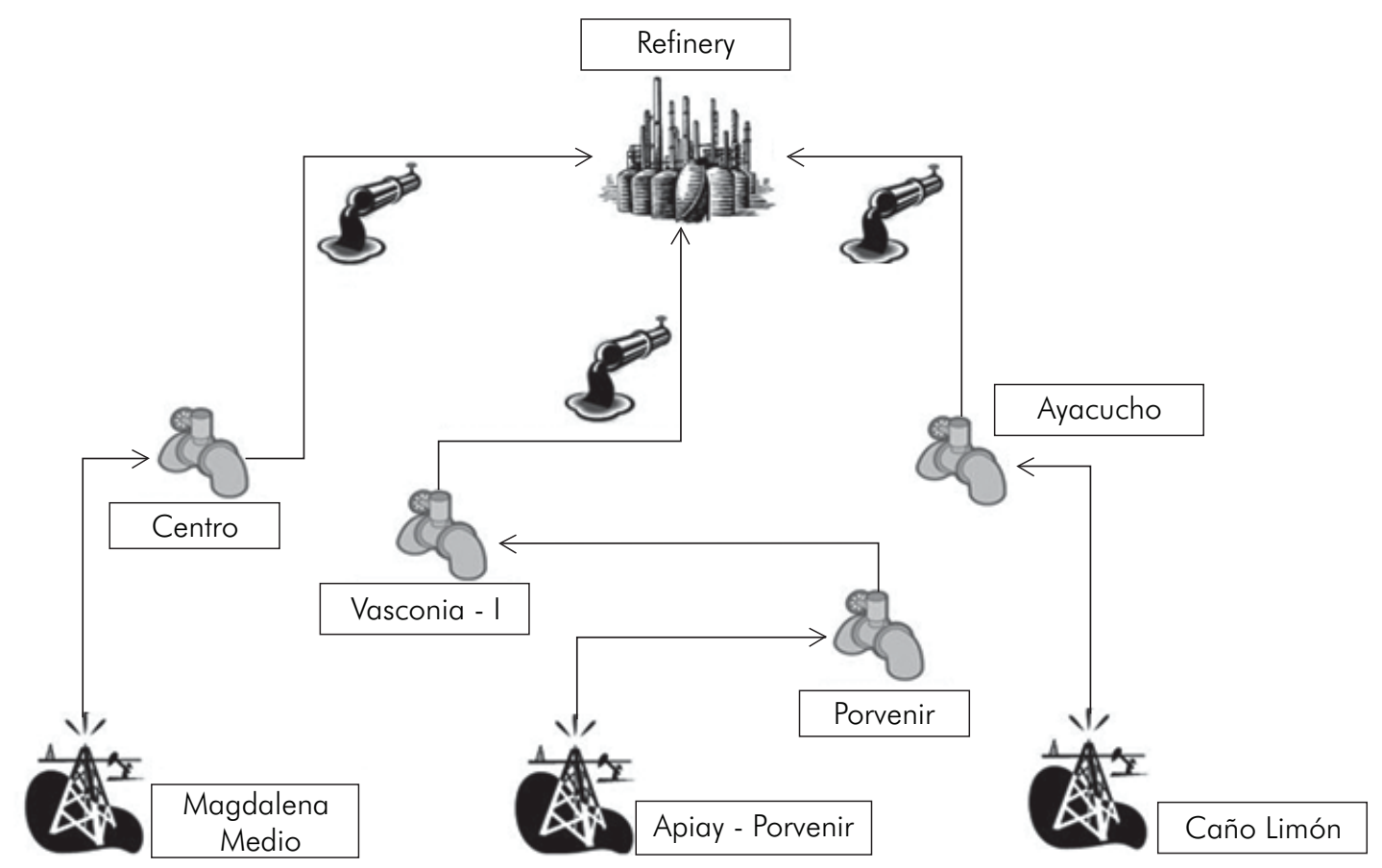

Figure 4. Main equivalent production oil fields and transport lines associated with the refinery.

Table 2. Main emissions factors, energy consumptions and product fractions obtained at the crude oil production stage. (Corporate Tool PRONET).

\begin{tabular}{|ccccc|}
\hline Products & Unit & Caño Limón & Apiay & Middle Magdalena \\
Crude & ton & 0,974 & 0,95 & 0,793 \\
\hline Natural Gas & ton & 0,026 & 0,05 & 0,207 \\
\hline Total Products & ton & 1,0 & 1,0 & 1,0 \\
Emissions Factors and Consumptions & $\mathrm{kW} \cdot \mathrm{h}_{\text {(e) }} /$ ton Crude & $1-5$ & $21-8$ & $8-15$ \\
\hline Electric Power & $\mathrm{kg} /$ ton Crude & $0,1-3 \mathrm{E}-01$ & $1-5 \mathrm{E}-01$ & $1-5$ \\
\hline Methane & $\mathrm{kg} /$ ton Crude & $1-5 \mathrm{E}+01$ & $4-12 \mathrm{E}+01$ & $3-10 \mathrm{E}+01$ \\
\hline Carbon Dioxide & $\mathrm{kg} /$ ton Crude & $3-10 \mathrm{E}-06$ & $1-8 \mathrm{E}-04$ & $1-10 \mathrm{E}-04$ \\
\hline Dinitrogen Oxide & & & \\
\hline
\end{tabular}


- The direct emissions caused by the generation of electric power (diesel, natural gas and crude oil combustion processes) at all the crude production centers were taken into consideration, based on the emission factors estimated by the EPA (Chapter AP-42). Otherwise, the indirect emissions such as venting o leakage were not taken into account in this study.

- The allocation of environmental loads for both natural gas and crude oil produced is based on energy criteria according to the low calorific value of the products (Wang, Lee \& Molburg, 2004). The allocation values of the environmental load at the production stage are $92,3 \%$ and $7,7 \%$ for crude and natural gas, respectively.

- This does not include emissions associated with the processes of infrastructure, machinery and facilities because their potential impact is diluted throughout the life of the capital goods used (Sheehan, Camobreco, Duffield, Graboski \& Shapouri, 1998).

\section{Transport of Crude and Refined Products}

- It is assumed that crude is transported by pipeline, because it is the main form of transport from the crude production sites to the refinery. Other types of transport (such as tank truck) were not taken into consideration in this study.

- There are three main lines to feed crude to the refinery: A transport line corresponding to the Caño Limon-Ayacucho-Refinery, a second line, which is the Ocensa pipeline (Apiay-Porvenir-Vasconia-Refinery), and finally the equivalent line that goes from the Magdalena Medio to the refinery (Figure 4).

- These lines to transport crude to the refinery have been established based on the volumetric load of crude fed to the refinery in 2008 .

- Table 3 illustrates the main characteristics of the equivalent transport lines, emissions factors and relevant energy consumptions that were established forthis study, related to the average distance between the equivalent production field and the refinery, as well as the crude fractions that make up the crude feed in the refining process. The combination of these variables provides the mass load of crude transported a length of $1 \mathrm{~km}$. expressed in units of ton-kilometer $(\mathrm{t} \cdot \mathrm{km})$.

Table 3. Main characteristics of the lines for crude oil transported (Corporate Tool SINOPER).

\begin{tabular}{|c|c|c|c|c|}
\hline Crude Transport Parameters & Unit & Caño Limón & Apiay & Middle Magdalena \\
\hline Amount of oil crude transported & ton & 1,0 & 1,0 & 1,0 \\
\hline Average distance oil field to refinery & $\mathrm{km}$ & 583,8 & 657,8 & 57 \\
\hline Load fraction of oil crude to refinery & - & 0,174 & 0,630 & 0,196 \\
\hline Oil crude trasported to refinery & $t \cdot \mathrm{km}$ & 101,6 & 414,4 & 11,2 \\
\hline \multicolumn{5}{|l|}{ Emissions Factor and Consumptions } \\
\hline Electric Power & $\mathrm{kW} \cdot \mathrm{h}_{(e)} / \mathrm{t} \cdot \mathrm{km}$ & $1-3 \mathrm{E}-03$ & $2-4 \mathrm{E}-03$ & $1-4 \mathrm{E}-03$ \\
\hline Methane & $\mathrm{kg} / \mathrm{t} \cdot \mathrm{km}$ & $2-4 \mathrm{E}-05$ & $1-4 \mathrm{E}-05$ & $1-4 \mathrm{E}-05$ \\
\hline Carbon Dioxide & $\mathrm{kg} / \mathrm{t} \cdot \mathrm{km}$ & $1-3 \mathrm{E}-02$ & $2-5 \mathrm{E}-02$ & $2-5 E-02$ \\
\hline Dinitrogen Oxide & $\mathrm{kg} / \mathrm{t} \cdot \mathrm{km}$ & $5-8 \mathrm{E}-07$ & $7-10$ E-07 & $7-10 \mathrm{E}-07$ \\
\hline
\end{tabular}

tkm: ton-kilometer crude transported 
Table 4. Main characteristics of the lines for refined transport (Corporate Tool SINOPER).

\begin{tabular}{|c|c|c|}
\hline Refined transported Parameters & Unit & Value \\
\hline Amount of products transported (DS3000 and/or DS500) & ton & 1,0 \\
\hline Average distance refineryto end user & $\mathrm{km}$ & 509,07 \\
\hline Transported products (DS3000 and/or DS500) & $\mathrm{t} \cdot \mathrm{km}$ & 509,07 \\
\hline \multicolumn{3}{|l|}{ Emissions Factor and Consumptions } \\
\hline Electric Power & $k W \cdot h_{(e)} / t \cdot k m$ & $3-6 \mathrm{E}-03$ \\
\hline Methane & $\mathrm{kg} / \mathrm{t} \cdot \mathrm{km}$ & $1-4 \mathrm{E}-04$ \\
\hline Carbon Dioxide & $\mathrm{kg} / \mathrm{t} \cdot \mathrm{km}$ & $2-5 \mathrm{E}-05$ \\
\hline Dinitrogen Oxide & $\mathrm{kg} / \mathrm{t} \cdot \mathrm{km}$ & $2-5 E-09$ \\
\hline
\end{tabular}

tkm: ton-kilometer of refined

- The transport of refined products through the pipeline called Departamento de Operaciones Andina (Department of Andean Operations) was taken as a reference for this study. The study also assumes the transport of refined products between the refinery and the Puente Aranda Station (Bogotá D. C.). The main features of this multi-purpose pipeline are described in Table 4 , including the main emissions factors and energy consumptions.

- The allocation of environmental loads to refined products transported by the pipeline is based on mass criteria, according to the volumetric load by pipeline during the reference year of operation 2008.

\section{Crude Refining}

- The crude refining process is subdivided into two global "black box" systems. One is the thermo-chemical refining process, and the other global module is the industrial service system, which involves processes for the conversion of primary energy to generate heat and electricity.

- Table 5 sets out the main products obtained in the industrial service and refining process, along with the respective percentages for the allocation of environmental loads. Regarding thermo-chemical refining processes, mass allocation factors were used as energy content is not available for the some products of the refinery, particularly the so-called "Refinery Others".

Table 5. Main products produced at the refinery and distribution percentages of environmental loads (Corporate Tool RIS \& PI).

\begin{tabular}{c|cc|}
\hline Refined Products & Unit & Mass allocation \\
Regular Gasoline & $\%$ & 20,03 \\
\hline Diesel DS3000 & $\%$ & 25,4 \\
\hline JET & $\%$ & 5,9 \\
\hline Residual Gas & $\%$ & 2,4 \\
\hline Fuel Oil & $\%$ & 13,0 \\
\hline Refinery Others & $\%$ & 33,0 \\
\hline Industrial Products Services & Unit & Energy allacation \\
\hline Electric Power & $\%$ & 38,3 \\
\hline Process Steam & $\%$ & 61,7 \\
\hline
\end{tabular}


- The allocation of environmental loads described in Table 5 is based on mass criteria for the case of refinery products, while industrial service products are distributed based on energy criteria in accordance with the recommendations of Lechón (2006) and data availability. Other criteria can be used such as economic, exergy or thermo-economic.

- In the case of DS500 production, the same energy consumption and emissions as determined for DS3000 have been assumed, with the inclusion of the consumption and emissions generated by the hydrotreatment process required to obtain DS500. Table 6 shows the main emissions factors and energy consumption for the two cases studied.

\section{Use of Regular Diesel}

- The emission factors available in the Ecoinvent database and Simapro 7.2 ${ }^{\circledR}$ in Table 7 have been used. These emission factors correspond to those evaluated in the operation of a 2005 European truck, EURO3, with an internal combustion diesel engine.

- The functional unit selected for the chain to process and obtain regular diesel is $1 \mathrm{MJ}$ of fossil fuel produced, while for the end-use, the functional unit is the distance travelled (1 kilometer - km) per one vehicle. In order to integrate both, the production of the fossil fuel and its respective end-use, a homogeneous functional unit is required. Thus the

Table 6. Main emission factors and energy consumptions on the crude oil refining (Corporate Tool RIS \& PI).

\begin{tabular}{|c|c|c|c|}
\hline Emissions Factors and Consumptions & Unit & Diesel DS500 & Diesel DS3000 \\
\hline Amount of diesel produced & $\mathrm{kg}$ & 1000 & 1000 \\
\hline \multicolumn{4}{|l|}{ Energy Consumptions/Ton Diesel } \\
\hline Thermal Energy & $k W \cdot h_{(t h)}$ & $250-350$ & $200-300$ \\
\hline Electric Power & $k W \cdot h_{(e)}$ & $15-30$ & $15-35$ \\
\hline Steam Process 600 Psi & $k W \cdot h_{(t h)}$ & $250-350$ & $250-350$ \\
\hline Steam Process 400 Psi & $k W \cdot h_{(t h)}$ & $150-250$ & $150-250$ \\
\hline Steam Process 150 Psi & $k W \cdot h_{(t h)}$ & $350-450$ & $250-350$ \\
\hline \multicolumn{4}{|l|}{ Raw Materials } \\
\hline Produced Oil Crude & $\mathrm{kg}$ & 1000 & 1000 \\
\hline Hydrogen & $\mathrm{kg}$ & $3-10$ & 0,0 \\
\hline \multicolumn{4}{|l|}{ Air Emissions / Ton Diesel } \\
\hline Nitrogen Oxides & $\mathrm{kg}$ & $0,06-0,19$ & $0,06-0,19$ \\
\hline Carbon Monoxide & $\mathrm{kg}$ & $15-25$ & $15-25$ \\
\hline Sulfur Oxides & $\mathrm{kg}$ & $0,5-2$ & $0,5-2$ \\
\hline Particulates $(<10 \mu \mathrm{m})$ & $\mathrm{kg}$ & $0,10-0,40$ & $0,10-0,40$ \\
\hline Volatile Organic Compounds & $\mathrm{kg}$ & $0,4-1,5$ & $0,4-1,5$ \\
\hline Carbon Dioxide & $\mathrm{kg}$ & $100-200$ & $100-200$ \\
\hline Dinitrogen Oxide & $\mathrm{kg}$ & $0,0003-0,001$ & $0,0003-0,001$ \\
\hline Methane & $\mathrm{kg}$ & $0,01-0,1$ & $0,01-0,1$ \\
\hline
\end{tabular}


Table 7. Parameters and emission factors considered in the fuels end use (Data base Ecoinvent, Truck EURO3_2005).

\begin{tabular}{|c|c|c|}
\hline Parameters & Diesel DS3250 & (*) Diesel DS500 \\
\hline Sulfur content (ppm) & 3250 & 500 \\
\hline Density $(\mathrm{kg} / \mathrm{m})^{3}$ & 840,0 & 840,0 \\
\hline $\mathrm{LHI}(\mathrm{MJ} / \mathrm{kg})$ & 42,80 & 42,29 \\
\hline Vehicle performance (km/gal) & 11,34 & 11,34 \\
\hline \multicolumn{3}{|l|}{ Emissions Factors } \\
\hline$H C(g / M J)$ & $0,0119-0,06$ & $0,0119-0,06$ \\
\hline $\mathrm{NO}_{x}(\mathrm{~g} / \mathrm{MJ})$ & $0,590-1,3351$ & $0,590-1,3351$ \\
\hline $\mathrm{CO}(\mathrm{g} / \mathrm{MJ})$ & $0,250-0,4589$ & $0,250-0,4589$ \\
\hline $\mathrm{CO}_{2}(\mathrm{~g} / \mathrm{MJ})$ & $73,097-94,2$ & $73,097-94,2$ \\
\hline$M P(g / M J)$ & $0,040-0,050$ & $0,040-0,050$ \\
\hline $\mathrm{SO}_{x}(\mathrm{~g} / \mathrm{MJ})$ & $0,0759-0,160$ & $0,025-0,0274$ \\
\hline
\end{tabular}

HC: Hydrocarbons; LHV: Low heat value; MP: Particulates matter $\left(^{*}\right)$ Inferred data

vehicle's performance in terms of fuel consumption per kilometer must be used and then this consumption has to be converted to equivalent energy consumed according to the lower calorific value of fossil diesel. Under these considerations, was obtained the homogeneous functional unit for the entire production chain and the end-use, as well as the emission factors in terms of grams of substance per MJ of diesel.

- The same emission factors were taken into consideration for both fuels studied, except in the case of sulfur oxide $\left(\mathrm{SO}_{X}\right)$ emissions, where they differ as a result of the initial sulfur content in the fuel.

- The main emissions affected by the hydrotreatment process are considered to be $\mathrm{SO}_{X}$ emissions during the diesel combustion process, which were estimated according to the stoichiometry of sulfur oxidation present in the two types of fuel evaluated.

\section{RESULTS}

Figure 5 compares the two scenarios of diesel production and use, considering only the category "Global
Warming" and using $1 \mathrm{MJ}$ of energy as the functional unit. The IPCC-2007 (GWP-100 years) method was used to evaluate the impact category mentioned above, finding a slight increase in the carbon footprint for DS500. This is a result of the additional hydrotreatment process required for diesel desulfurization, which increases the specific emissions (g $\mathrm{CO}_{2}$-eq/ MJ Diesel).

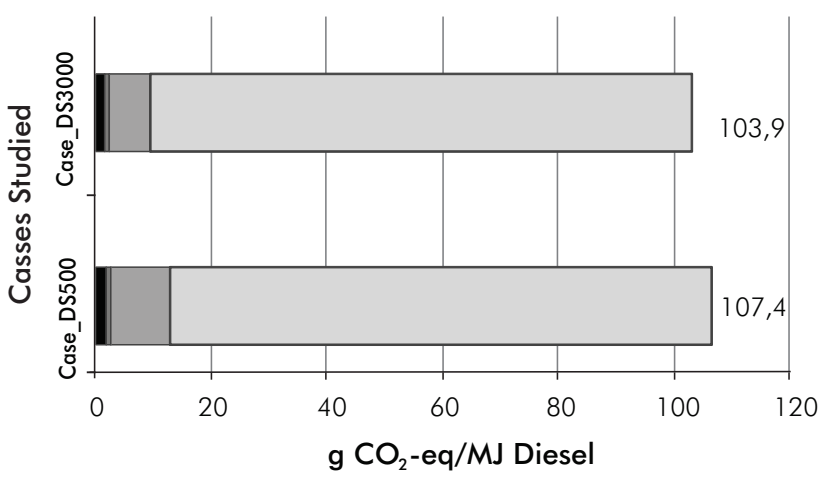

Oil_Production

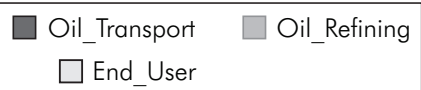

Figure 5. Contributions by stages of fossil fuel production chain to category "Global Warming". (g $\mathrm{CO}_{2}$-eq/ MJ Diesel). 
Similarly, Figure 5 shows the total $\mathrm{g} \mathrm{CO}_{2}$-eq/ $\mathrm{MJ}$ Diesel for each of the products in question, where DS3000 reaches a total of $104 \mathrm{~g} \mathrm{CO}_{2}$-eq/ MJ Diesel, while DS500 presents a total of $107 \mathrm{~g} \mathrm{CO}$-eq/ MJ Diesel, where the refining stage is the process in which the biggest changes occur, with a 3,33\% increase in carbon intensity compared to DS3000. On another note, Table 8 shows the percentage contributions to "Global Warming" of each of the stages of the production chain of the fuels studied, in terms of $\mathrm{g} \mathrm{CO}_{2}$-eq/ MJ Diesel. This shows that the biggest contribution to the "Global Warming" category goes to the fuel end-use stage, which reaches values of approximately $85 \%$ to $90 \%$ in both cases.

Figure 6 shows the percentage of reduction for each of the impact categories evaluated, when comparing the products under study. This shows a reduction of over $80 \%$ for DS500 compared to DS3000 mainly in the categories: "Land Acidification", "Water Acidification" and respirable inorganic particles. This is the result of the reduction in $S O_{X}$ emissions generated during the end-use of DS500. On another note, the operation of the hydrotreatment plant for the process to desulfurize and obtain DS500 leads to a slight increase in the environmental impact in relation to DS3000, in terms of "Global Warming" and "Non-renewable Energy" with increases of $2 \%$ and $6 \%$, respectively.

Figure 7 shows the reduction percentages for the different categories of eventual damage. According to the impact assessment method selected (Impact 2002+), the categories described in Figure 6 are transformed into categories of eventual impact (Human Health,

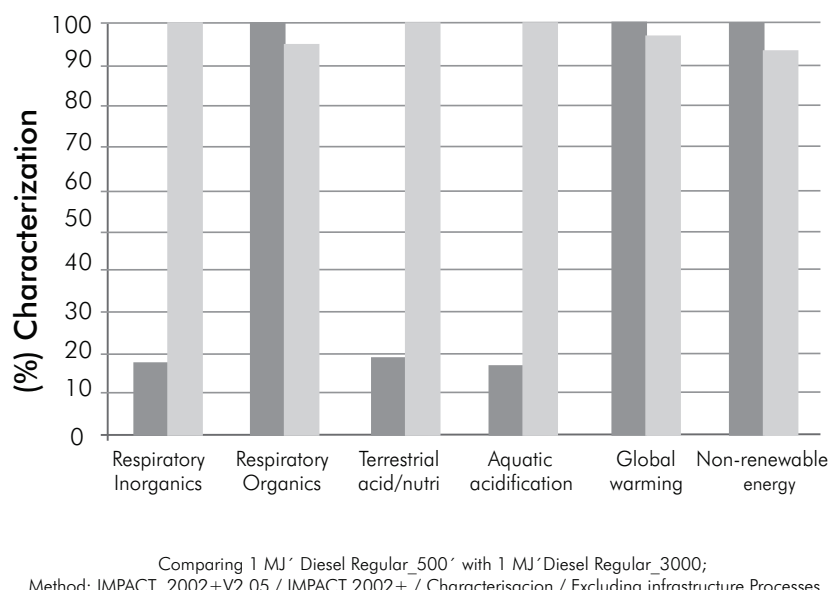

Method: IMPACT 2002+V2.05 / IMPACT 2002+ / Characterisacion / Excluding infrastructure Processes

$$
\text { - Case_DS500 Case_DS3000 }
$$

Figure 6. Comparison of impact categories between the evaluated scenarios.

Ecosystem Quality, Climate Change and Natural Resources) based on damage factors. When considering the potential impacts associated with "Human Health" and "Ecosystem Quality", the production and use of DS500 show reductions of more than $80 \%$ compared to the process of DS3000. The opposite is the case when assessing the categories of "Climate Change" and "Depletion of Natural Resources", where DS500 presents minimal increases (2-6\%) compared to DS3000.

Accordingly, it can be observed that the emissions of criteria pollutants $\left(C O, S O_{X}, N O_{X}, V O C\right.$ 's y MP) have a greater contribution to the categories of "Human Health" and "Ecosystem Quality", while $\mathrm{NO}_{2}, \mathrm{CH}_{4}$ y $\mathrm{CO}_{2}$ emissions have a direct impact on the categori es of "Climate Change" and "Depletion of Natural Resources".

Table 8. Percentage contributions by stages to the "Global Warming" category .

\begin{tabular}{|c|c|c|c|c|}
\hline \multirow{2}{*}{$\begin{array}{l}\text { Stages of the Production Chain } \\
\text { and Fuel End - Use }\end{array}$} & \multicolumn{2}{|c|}{ Diesel DS500 } & \multicolumn{2}{|c|}{ Diesel DS3000 } \\
\hline & $\mathrm{g} \mathrm{CO}_{2}$-eq/MJ Diesel & $\%$ & $\mathrm{~g} \mathrm{CO}_{2}$-eq/MJ Diesel & $\%$ \\
\hline Oil Production & 1,91 & $1,78 \%$ & 1,83 & $1,76 \%$ \\
\hline Oil Transport & 0,76 & $0,71 \%$ & 0,79 & $0,76 \%$ \\
\hline Oil Refining & 10,43 & $9,71 \%$ & 7,02 & $6,76 \%$ \\
\hline Refined Transport & 0,068 & $0,06 \%$ & 0,068 & $0,07 \%$ \\
\hline Fuel End - Use & 94,2 & $87,74 \%$ & 94,2 & $90,66 \%$ \\
\hline Total & 107,4 & $100 \%$ & 103,9 & $100 \%$ \\
\hline
\end{tabular}




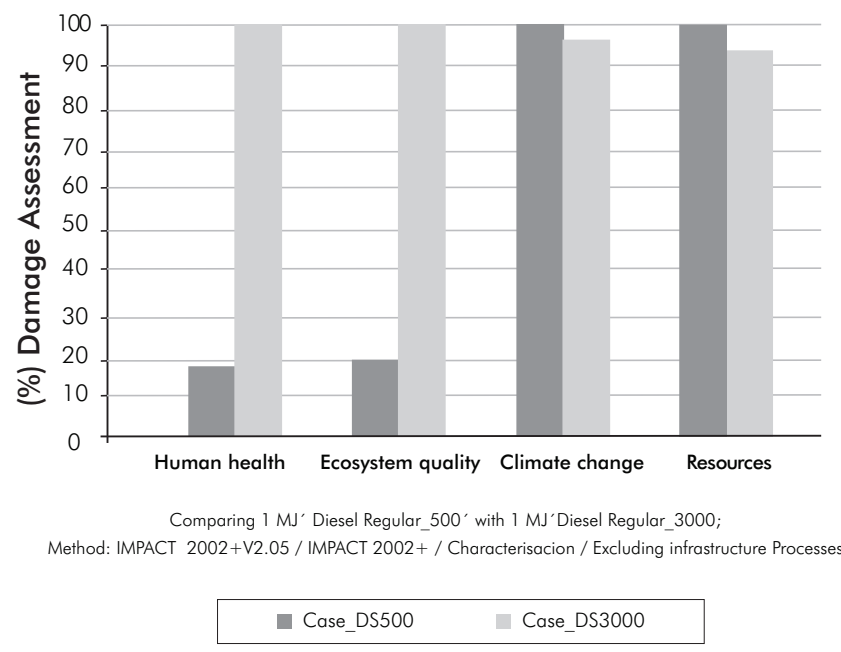

Figure 7. Assessing the damage category for each of the studied scenarios.

All the damage or final impact categories evaluated can be added and quantified in a single variable called "Single Score", measured in milli points (mPt). Figure 8 shows the final single score of the environmental impacts caused during the production and use of DS3000 and DS500, reaching total scores of environmental impact between 1,23 and 0,23 $\mathrm{mPt}$, respectively. Therefore, considering all environmental aspects such as single score, the reduction of sulfur in fuel to obtain DS500 causes less environmental impact (lowest single score) compared to DS3000, even though DS500 requires an additional hydrotreatment process and therefore, a higher demand for fossil resources.

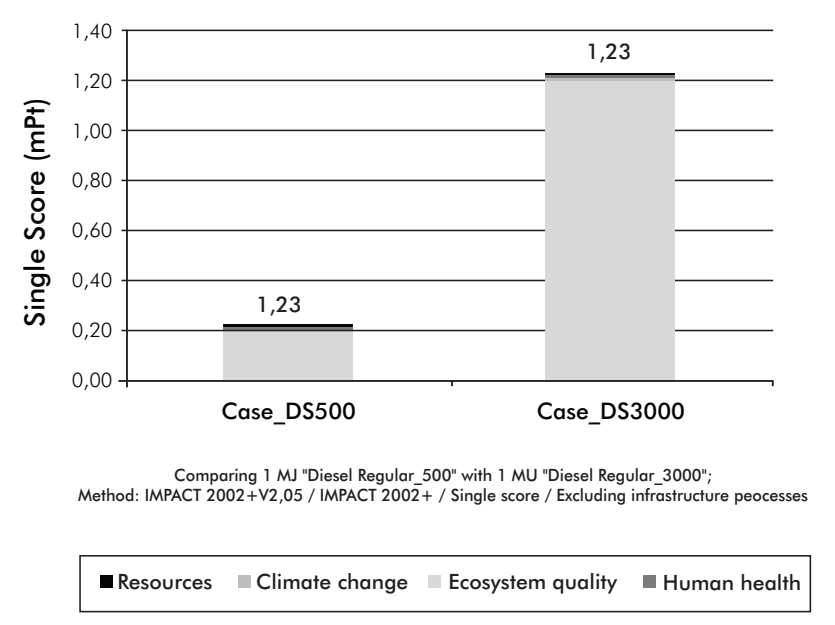

Figure 8. Single score the final environmental impact for each of the studied scenarios.

\section{CONCLUSIONS}

- Due to the emissions generated by the additional hydrotreatment process required for the production of DS500, a value of 107,4 $\mathrm{g} \mathrm{CO}$-eq/MJ was found as regards the carbon footprint in this fuel, which is a $3,8 \%$ increase with reference to the same variable in $\operatorname{DS} 3000\left(103,9 \mathrm{~g} \mathrm{CO}_{2}\right.$-eq/MJ).

- The comparative LCA of the fuels studied allowed the estimation of the reduction percentages for each of the environmental impact categories taken into consideration. Thus, DS500 showed a significant reduction of $82 \%$ in the "Land Acidification" category, nearly $83 \%$ in "Water Acidification" and $82 \%$ for the "Respirable Inorganic Particles" environmental variable when compared to DS3000. However, a slight increase was noted in the case of DS500 in relation to the categories of "Global Warming" and "Non-renewable Energy", with rates of about 2,5\% and $6,2 \%$, respectively.

- When considering the potential impacts associated with "Human Health" and "Ecosystem Quality", the production and use of DS500 show reductions of $82,8 \%$ and $81,6 \%$ respectively, compared to the DS3000 process. The opposite is the case when assessing the categories of "Climate Change" and "Depletion of Natural Resources", where DS500 presents minimal increases of $2,5 \%$ and $6,2 \%$ respectively compared to DS3000.

- Applying the Impact 2002+ method allowed the estimation of the "Single Score" of the total environmental impact for each case that was simulated, where DS3000 was the scenario with the highest score $(1,23 \mathrm{mPt})$ causing significant impacts, mainly in the categories of "Ecosystem Quality" and toxicity to "Human Health", while the production and use of DS500, despite an increase the carbon footprint, resulted in a single score of $0,23 \mathrm{mPt}$, indicating a lower overall environmental impact compared to DS3000.

- On another note, it shows the application of the life cycle analysis methodology as an innovative tool for understanding environmental phenomena. This type of study should be updated with Ecopetrol's new projects in the modernization of its refineries. 


\section{ACKNOWLEDGMENTS}

We would like to thank the Clean Technologies team of the Ecopetrol S.A.- Instituto Colombiano del Petróleo (ICP) for providing information on emissions inventories. We would also like to extend our thanks to all the professionals at the ICP that took part in the information validation process associated with crude production, transport and refining, as well as the transport of refined products.

\section{REFERENCES}

Arango, J. H. (2009). Calidad de los combustibles en Colombia. Revista de Ingeniería de la Universidad de Los Andes de Colombia, 29: 100-108.

Cape, J. (2003). Direct damage to vegetation caused by acid rain and polluted cloud: Definition of critical levels for forest trees. J. Env. Poll., 82 (2), 167-180.

Chunshan, S. \& Xiaoliang, M. (2009). New design approaches to ultra-clean diesel fuels by deep desulfurization and deep dearomatization. J. App. Cat. B: Env., 4: 207-238.

Herrera, M. \& Martínez, E. (2009). Generación de inventario de emisiones atmosféricas: gases de efecto invernadero y contaminantes criterio en la GRB. Informe final y reporte de emisiones atmosféricas. Tecnologías Limpias. Ecopetrol S.A. - Instituto Colombiano del Petróleo (ICP).

ISO 14044 (2007). Life cycle assessment - Requirements and guidelines. V2, edited Instituto Colombiano de Normas Técnicas (ICONTEC).

Jolliet, O., Margni, M., Charles, R., Humbert, S., Payet, J., Rebitzer, G. \& Rosenbaum, R. (2003). A new life cycle impact assessment methodology IMPACT 2002+ . Int J. Life Cyc. Asses., 8 (6), 324-330.

Law 1205 (2008). Based on which the quality of life is improved by means of the quality of diesel and other provisions are handed down. Congreso de la República de Colombia.

Lechón, Y. (2006). Análisis de ciclo de vida de combustibles alternativos para el transporte - fase II. Informe Técnico, Centro de Investigaciones Energéticas Medioambientales y Energéticas de España (CIEMAT).
Menz, F. \& Seip, H. (2004). Acid rain in Europe and the United States: an update. J. Env. Scie. \& Policy, 7(4), 253-265.

Mester, Z. (2000). Trends in diesel fuel sulfur regulations. Congress and National Meeting No.220, Washington, United State.

Plantenga, F. L. \& Leliveld, R. G. (2003). Sulfur in fuels: more stringent sulfur specifications for fuels are driving innovation. Applied Catalysis A., 248 (1-2), 1-7.

Resolution 180947 (2010). Based on which the emission factor is estimated for the generation of electric power in Colombia. Ministerio de Minas y Energía (MME) de Colombia.

Resolution 182087 (2007). Based on which the quality criteria of biofuels are modified for their use in diesel engines. Ministry of the Environment, Housing and Territorial Development (MAVDT) and the Ministry of Mines and Energy (MME)

Sheehan, J., Camobreco, V., Duffield, J., Graboski, J. \& Shapouri, H. (1998). Life cycle inventory of biodiesel and petroleum diesel for use in an urban bus. Final Report May. Department of Energy and Department of Agriculture from U.S. - National Renewable Energy Laboratory (NREL), 53-94.

Stanislaus, A., Abdulazeem, M. \& Mohan, S. R. (2010). Recent advances in the science and technology of ultra low sulfur diesel (ULSD) production. J. Cat. Tod., 153 (1-2), 1-68.

Sydbom, A., Blomberg, A., Parnia, S., Stenfors, N., Sandstrom, T. \& Dahlen, E. (2001). Health effects of diesel exhaust emissions. Eur. Respirator J., 17: 733-743.

Téllez, M. (2010). Ecopetrol S.A. Inaugura moderna planta para producir combustibles limpios. Boletín Técnico, Ecopetrol S.A. [On line]. [Accessed: May 2011]. Available at: $<$ http://www.ecopetrol.com.co/contenido.aspx?catID $=14$ $8 \&$ conID $=43701 \&$ pagID $=132961>$

Wang, M., Lee, H. \& Molburg, J. (2004). Allocation of Energy Use in Petroleum Refineries to Petroleum Products Implications for Life-Cycle Energy Use and Emission Inventory of Petroleum Transportation Fuels. Int J. Life Cyc. Asses., 9 (1), 34-44. 